\title{
Factors Influencing Growth of Dairy Farming Business in Amentia South District of Mere County, Kenya
}

\author{
Muriuki Kiboi Muriithi ${ }^{1}$ and Guyo S. Huka ${ }^{2}$ and Ibuathu Charles Njati ${ }^{3}$ \\ ${ }^{I}$ Msc Entrepreneurship Student, Meru University of Science and Technology \\ ${ }^{2,3}$ Lecturer, Meru University of Science and Technology
}

\begin{abstract}
National level production of livestock and livestock products in Kenya has increased over the years even though many households involved in livestock production have continued to be poor and food insecure. It is perceived that poor performance of dairy businesses is stemming from poor business growth caused by certain business related factors. Consequently, a study was conducted to establish factors influencing business growth of smallholder dairy farming enterprises in Imenti South District of Meru County, Kenya. The objectives of the study were to establish the influence of farmer's business management skills, and extension support services on the growth of dairy farming business. The study also explored complementary relationships between dairy farmers and horticultural crops growers in the study region. The research employed descriptive survey design using questionnaires. The study had a target population of 5,993 farmers selling milk through cooperative societies or milk marketing groups in Imenti South District. Sample sizes of 190 dairy farmers were randomly selected using systematic proportionate random sampling technique. The study established that business management skills influence growth of diary enterprises and that interaction with extension service providers positively impacted on the earnings of the dairy farmers. Further it was established that the size of the dairy businesses are not directly related to age of the enterprises implying stagnation of the older enterprises as it is not consistent with growth model of business enterprises. Joint venture between dairy farming and horticultural crop growing were also found to be beneficial to farmers in the study areas because of its complementary nature through use of manures for horticulture.
\end{abstract}

Key Words: business management skills, extension services, business training, business growth

\section{Background to the study}

The dairy sector is very important in its contribution to the economies of both the developed and the developing countries of the world. However, there are big variations in production systems and productivity between the two. In the developed countries, the production is mostly by large scale enterprises with competitive management systems and high uptake of technology and big capital outlay while in the developing countries it is largely by small scale farmers with minimum management and technical skills, limited access to capital and low access to information. This has resulted to disparities in production levels in developing and developed economies. Studies have shown that Argentina produces 3,500 liters /cow/year, Germany 7,100 liters/cow/year and USA 9,000 liters/cow/year (EADDP, 2008) and Australia 5,750 liters/cow/year, China 3,700 liters/cow/year, India 956 liters/cow/year, Newzeland 3,868 liters/cow/year (FAO, 2010).India is the biggest producer of milk in the world while Newzeland is the world's largest exporter of dairy products. In the European Union member countries, production of milk is through allocation of quotas per country and therefore production is pre-determined.

In Africa, Kenya is among the big producers of milk leading all the east African countries. South Africa has the most efficient production system and produces 2,500 liters/ cow/year compared to 800 liters/cow/year in Uganda, 1,000 liters/cow/year in Tanzania and 1,800 liters/cow/year in Kenya (FAO, 2010). The Kenyan dairy industry can be benchmarked to dairy industries in China, India and Australia. All these countries have a production system similar to the one in Kenya which is low cost because it is based on rain fed pasture production (GOK, 2010).

In Kenya, the dairy industry is the single largest agricultural sub-sector, larger than even tea (Muriuki, 2003). It contributes 14 percent of agricultural GDP and 3.5 percent of total GDP (GOK, 2008). Although Kenya's dairy sector has a significant contribution to the national economy, household incomes and food security, the industry faces a number of technical, economic and institutional problems in milk production, processing and marketing. These constraints affect the ability of the sector to participate and compete in the domestic and regional markets (Wambugu.S, Kirimi.L and Opiyo. J, 2011). Milk production in Kenya is predominantly by small scale farmers, who own one to three animals, and produce about 80 percent of the milk in the country. According to the Kenya dairy master plan over 1.8 million households are involved in milk based enterprises but in spite of this great role, the sector experiences low productivity, low profitability and 
slow enterprise growth (GOK, 2010). This might be caused by low levels of commercialization likely stemming from poor business management skills and poor extension support services.

Imenti South with 40,000 dairy cattle and 37,000 households produces an average of 2100 liters/cow/year. This is slightly above the national average of 1800 liters/cow/year documented in the national dairy master plan.It is estimated 20,000 households are smallholder dairy farmers in Imenti South district with each farmer having on average two cows (MOLD, 2011). The dairy cattle in the district are mostly kept under intensive management system because of the small land sizes.

\subsection{Statement of the problem}

In Kenya, the dairy industry is the single largest agricultural sub-sector and contributed 100 billion to the GDP in the year 2007.The country has 1.8 million milk based enterprises and is recognized in vision 2030 as an important driver of economic growth. Although production of livestock and livestock products on average at national level has increased over the years, many households continue to be poor and food insecure (GOK, 2008). This is because most of this growth has been due to increase in the number of farmers joining the industry while the existing enterprises have underperformed. This is reflected by the low productivity of the animals at an average of 1800 liters/cow per year. The Kenyan government over the past decade has recognized the challenges facing the dairy industry and interventions such as revival of the New Kenya cooperative creameries, restriction of milk powder importation and infrastructure improvement have been employed.

The dairy farming businesses in Imenti south are characterized by low productivity and profitability despite of the potential of the dairy cows to produce up to 6000 litres of milk/cow/year. This study therefore seeks to investigate the causes of this poor performance by analyzing the selected factors such as business management skills and extension support services that have significance in the dairy enterprises' growth.

\subsection{Objectives of the study}

1. To find out the influence of farmer's business management skills on growth of dairy farming enterprises in Imenti south district.

2. To establish the influence of extension support services on growth of dairy farming enterprises in Imenti south district

\section{Literature Review}

The purpose of starting any business venture is to create wealth. This is achieved through enterprise growth and development. This growth may be reflected in terms of profitability, revenue turn over, market share, customer base, business networks, capital base, size of enterprise and number of employees. After reviewing available reports in the district livestock production office in Ministry of Livestock Development (MoLD) reports from Imenti South district show that most dairy enterprises seem to have stagnated in their growth over the years. The production per cow per day is estimated at 8 liters (MOLD, 2011) with a profit margin of KES 2.30 per liter in the lower highlands (Mburu L.M, Gitu K.W and Wakhungu J.W, 2007). This is not enough revenue to sustain and grow the business and therefore the question as to how to improve growth of dairy enterprises by increasing productivity and size of business therefore persists. Preliminary investigations show that business management skills and extension service support services have significant roles in the dairy business growth and development.

\subsection{Farmers Business Management Skills}

Surveys of Ministry of Livestock Development have shown that many dairy farmers in Imenti South district operate without a business plan and operate on a trial and error basis. Many dairy farmers do not keep farm records and those who do have very scanty records (MoLD, 2011). The absence of such vital business documents significantly affects the decision making process as decisions are left to instinct and not based on sound business management principles. The extension agents who are in contact with the farmers are also ill equipped to offer quality business advisory services and stick to technical packages where they are conversant. This is suspected to be one of the reasons for poor performance of the dairy enterprises resulting to poor growth .One of the key areas in business management is strategic management.

Strategy entails the deployment of resources to achieve optimal organizational aims and objectives. This includes marshalling the firm's internal resources to meet the demands, challenges and the external operating environment in pursuit of its objectives (O'Regan and Ghobadian, 2004). In this study business plans, marketing plans and budgets were taken as part of strategic planning and their influence on growth established. The goals of any firm once they have been defined become the basis for planning and future development. Management planning and monitoring are crucial factors in guaranteeing the correct development course of a business as well as generating profits. Strategy is a key factor for the competitiveness and profitability of a company. Success in strategy implementation depends on the internal factors, such as the way the 
owner/manager makes decisions in the current environment and the human resource capacity as well as external variables. This study sought to establish the management strategies used by dairy farmers in managing their enterprises and the influence of such strategies or lack of them on productivity and profitability.

In Kenya's smallholder dairy sector, the appropriate combination of improved cattle breeds, artificial insemination services, specially formulated livestock feeds and improved veterinary services nearly quadruple milk production per cow (Ngigi et al., 2010) as cited in (Haggblade, 2011). This raises the question whether the real issues influencing productivity and profitability could be business management related and whether the dairy farmers in Imenti south district have adequate business management skills to drive growth of their enterprises. In addition, the study sought to establish the role of extension support service on the dairy productivity.

\subsection{Extension support services}

Strengthening of national agricultural support system has been advocated as a strategy for increasing agricultural production in Sub-Saharan Africa by governments in the region and by international development agencies (Evenson and Mwabu, 1998). In addition, investments in information and communication technologies have significantly improved the efficiency of agribusiness marketing systems in Africa (Haggblade, 2011). In turn, improved information flows lead to decreased price variability, lower risk premiums and hence lower marketing costs. In Imenti south information networks has been somehow enhanced by improving the extension service which is an important link with the market by providing necessary information to farmers and buyers.

Agricultural sector extension service plays a vital role in the sharing of knowledge, technologies, agricultural information and linking the farmer to other actors in the economy. The extension service is, therefore, one of the critical change agents required in the transformation of subsistence farming to modern and commercial agriculture, which is critically important in promoting household food security, improving incomes and reducing poverty (GOK, 2009).

A consensus exists that extension services, if functioning effectively, improve agricultural productivity through providing farmers with information that helps them to optimize their use of limited resources. Variations in management practices and husbandry skills among small farmers in Kenya are very wide. Achieving gains in agricultural production efficiency depends on many factors, but extension is likely to be among the most important (Muyanga and Jayne, 2006).

Extension plays a role in dairy enterprise growth through information dissemination, creating linkages with markets and service providers, and interactions with farmers to change negative attitudes and perceptions. This calls for a positive close relationship between the extension provider and the dairy entrepreneur in an environment of mutual trust. The declining effectiveness of the public extension service has been identified as one among the factors impeding agricultural growth in Kenya (Muyanga and Jayne, 2006).

Imenti South district has 20,000 dairy farmers covered by 10 public livestock extension providers (MOLD, 2011). This works out to a ratio of 1 extension officer to 2, 000 farmers. The recommendation is 1 livestock extension provider to 500 farmers (GOK, 2009). The question this disparity raises is whether the district is adequately covered to provide extension services and how this influences growth of the dairy enterprises.

In a study by Muchai (1999) the conclusion reached after the investigation and analysis was that the smallholder dairy businessmen require a lot of assistance in order to improve their business. The form of assistance needed may have to be diverse but can only succeed if carried out by a highly competent workforce. Assistance in form of advice to each businessman according to his unique situation will be needed and constant follow up to detect problems and correct them in time. This is the kind of assistance the study sought to qualify by understanding the factors that influence performance of the dairy enterprises. In this research the influence of extension services in growth of dairy businesses in terms of productivity, profitability and size of enterprise has been established and analyzed.

\subsection{Theoretical framework}

This study is grounded on the Churchill and Lewis (1983) growth model which is presented in figure 1. Churchill and Lewis (1983) developed a growth model, which explains the predictable growth pattern of a small-to-medium sized enterprise.

Churchill and Lewis (1983) growth model note that businesses go through five stages of growth: conception, survival, success, take-off, and maturity. The majority of the micro and small dairy enterprises remain at the conception and survival stages of growth and very few progress to the success status. This raises the question as to what factors contribute to this scenario and what can be done to have many more dairy businesses performing better to ensure success. There are internal and external influences on small firm formation and survival. The internal influences are; owner/manager motives, personal attributes, technical skills, strategic management competencies, entrepreneurial management behavior while the external influences are; macro and micro 
environment. In this study, enterprise internal and external factors at the micro-level that are suspected to greatly affect growth of dairy cattle enterprises have been selected. The internal factors is farmer's business management skills while the external factor is livestock extension support services availability. These two (2) factors may have direct influence on the productivity and profitability of dairy enterprises in Imenti South, Meru Kenya.

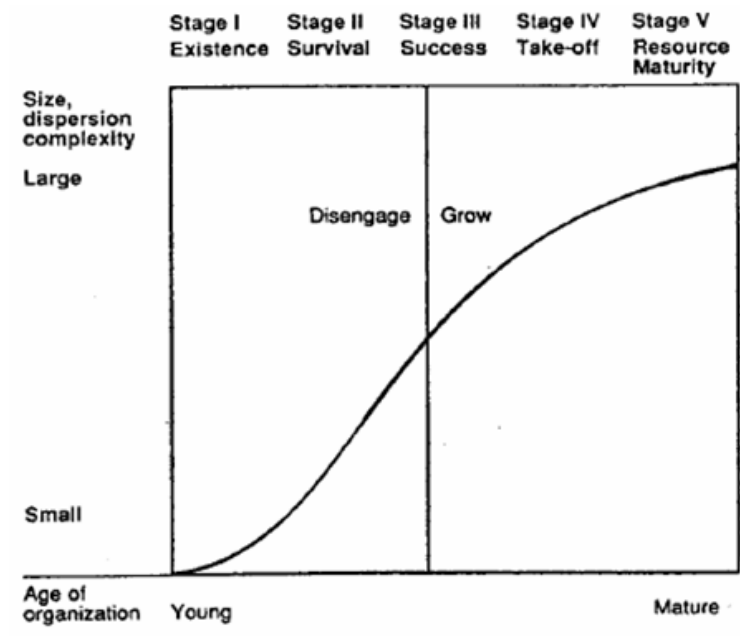

Figure 1: Churcill \& Lewis (1983) Growth Model

The model developed by Churchill and Lewis (1983) has five stages namely: existence, survival, success, take-off, and resource maturity. In the existence stage, the key focus is on obtaining customers and as such the extent of formal systems is minimal and in some cases non-existent. In addition, the organizational structure is flat and therefore the owner-manager adopts a management style where there is direct supervision of those working in the business.

As the business progresses to the second stage of survival, the business begins to employ some formal systems as the organizational structure develops more levels and hence, the owner-manager begins to delegate some of the responsibilities to employees or agents. The success stage is characterized by the owner-manager deciding either to keep the business at its current operational level or expand the business to higher growth. The decision will be driven by the owner-manager's motivation, opportunity recognition and resources. Technical managers are usually used in this stage since the business would normally have grown to sizeable scopes and more management responsibilities are required. In addition, the business has developed basic functional systems such as finance, marketing, and operations.

In the fourth stage of take-off, the key management issues confronting the owner-manager include determining the rate of growth and financing of the desired growth. Embedded in making these decisions are issues of delegation where the owner-manager would have to allow for even greater delegation to functional managers to improve organizational effectiveness and availability and access to financial resources required to support the desired growth. The final stage is resource maturity where the main concern for owner-managers includes managing the financial gains resulting from growth and maintaining the benefits associated with small business such as flexibility, responsiveness to customers' changing needs and entrepreneurial behavior. A business in this stage would typically have well-established organizational systems.

\subsection{Conceptual Framework}

In this study the factors under investigation were business management skills (internal environment) and extension support services. In a study by muchai (1999) it was confirmed that both external and internal factors do influence the performance of smallholder dairy businesses. Internal problems were perceived to be those directly associated with the businessmen themselves and are within famers control while external factors are those originating from the immediate environment and as such, owners have little control over them. It is expected that dairy enterprises belonging to farmers who are entrepreneurs and have business management skills would be more profitable. Besides, high interaction with dairy extension providers was also expected to influence faster growth of dairy enterprises reflected in higher profitability and productivity. However, government policy and regulations regarding infrastructure Development, funding to the sector and general state of economy are expected to influence the degree of dairy growth under the investigation as illustrated in figure 2 . 


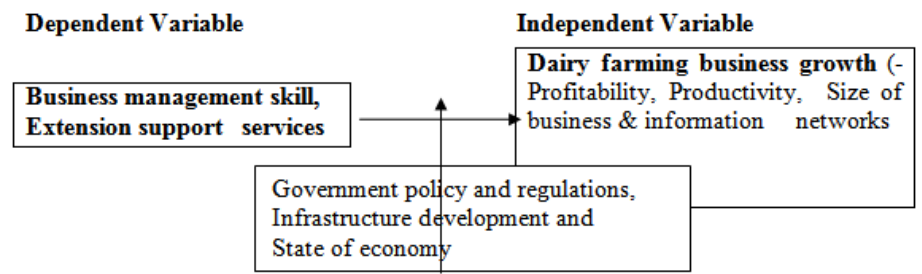

Figure 2: Conceptual Frameworks for Selected Factors Influencing Growth of Dairy Farming Businesses in Imenti South District

Figure 2 proposes that if the farmers have management skills in a supportive business environment and further supported through extension service their dairy businesses will grow. This growth would be reflected in higher productivity, higher profitability, bigger sized businesses and improved information networks.

However, the business growth can be influenced by government intervention through government policy in terms of regulations governing the dairy sector, infrastructure development like provision of milk cooling facilities and roads construction, government funding in terms of subsidies and incentives and by the general state of the economy.

\subsection{Research design}

\section{Research Methodology}

This research employs descriptive survey design. A descriptive survey research determines and reports the status of events or phenomenon without manipulation (Mugenda \& Mugenda, 2008). This study collected data, analyzed it and made generalizations on the influence of the selected factors, that is, business management skills and extension services on growth of dairy farming enterprises in Imenti South district of Meru county, Kenya.

\subsection{Sampling Frame}

Sampling entities represents the actual target population and comprises all the units that are potential members of a sample (Kothari, 2008, Mugenda, 2008). In this study, individual farmers from organized milk marketing groups in Imenti South district form sampling units as illustrated in table 1.

\subsection{Target population}

The target population of this study was all dairy farmers marketing milk through dairy societies or milk marketing groups in Imenti South district. There are 20 such groups in the district and all the members of these groups were taken as the target population. The choice of milk marketing groups is necessitated by the fact that farmers marketing their milk formally are more likely to view their farming as a business enterprise. The total membership of the groups is 5993 members as shown in table 1.

Table1: Dairy marketing groups in Imenti South District

\begin{tabular}{lll}
\hline S/No & Group Name & Membership \\
\hline 1 & Nkuene dairy society & 1523 \\
2 & Kigane dairy society & 357 \\
3 & Ndamene SHG & 45 \\
4 & Ukuu dairy society & 209 \\
5 & Uruku dairy society & 502 \\
6 & Mitioo dairv societv & 670 \\
7 & Kiamitumi SHG & 115 \\
8 & Kathugu SHG & 80 \\
9 & Karau SHG & 27 \\
10 & Mucokia maendeleo & 120 \\
12 & Mutonga SHG & 140 \\
13 & Kanyakine dairy society & 473 \\
14 & Mungano SHG & 300 \\
15 & Baranga SHG & 10 \\
16 & Baranga dairy society & 72 \\
17 & Igoki dairy society & 150 \\
18 & Igoki SHG & 380 \\
19 & Chure dairy society & 400 \\
20 & South Imenti Farmers company & 420 \\
& Total & $\mathbf{5 9 9 3}$ \\
\hline
\end{tabular}

Source: District Livestock Production Office, Imenti South District 
Factors Influencing Growth of Dairy Farming Business in Amentia South District of Mere County,

\subsection{Sampling procedures and sample size}

The sampling technique employed in this study was the stratified proportionate random sampling. The following formula provided by (Kothari,2004) was used to calculate the sample size for the study:

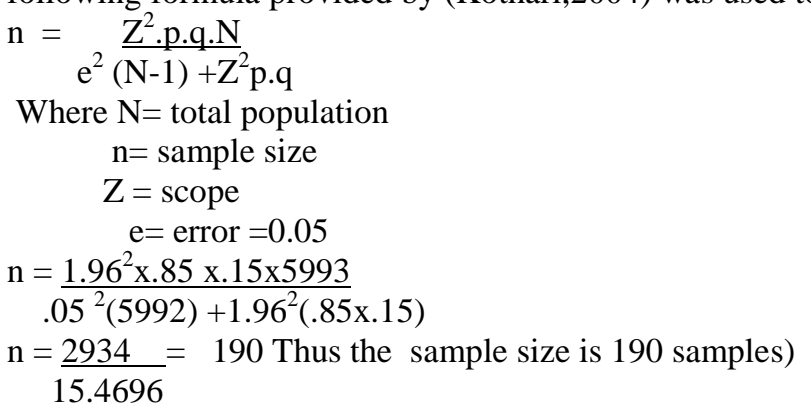

Table 2: Proportionate distribution of the samples among the dairy groups

\begin{tabular}{llll}
\hline & Group Name & Membership & Sample Size \\
\hline 1 & Nkuene dairy society & 1523 & 48 \\
2 & Kigane dairy society & 357 & 11 \\
3 & Ndamene SHG & 45 & 1 \\
4 & Ukuu dairy society & 209 & 7 \\
5 & Uruku dairy society & 502 & 16 \\
6 & Mitigo dairy society & 670 & 21 \\
7 & Kiamitumi SHG & 115 & 4 \\
8 & Kathugu SHG & 80 & 3 \\
9 & Karau SHG & 27 & 1 \\
10 & Mucokia maendeleo & 120 & 4 \\
12 & Mutonga SHG & 140 & 4 \\
13 & Kanyakine dairy society & 473 & 15 \\
14 & Mungano SHG & 300 & 10 \\
15 & Baranga SHG & 10 & 0 \\
16 & Baranga dairy society & 72 & 2 \\
17 & Igoki dairy society & 150 & 5 \\
18 & Igoki SHG & 380 & 12 \\
19 & Chure dairy society & 400 & 13 \\
20 & South Imenti Farmers Company & 420 & 13 \\
& Total & $\mathbf{5 9 9 3}$ & $\mathbf{1 9 0}$ \\
\hline
\end{tabular}

\subsection{Research instruments}

Reliability of the instrument was ascertained by pre-testing the questionnaire with a population similar to the target population in Meru central district.10\% of sample size was used. Further, the researcher used content validity which was assessed by professors in the School of Business and Economics of Meru University of Science and Technology and experts in the dairy sector from Kenya Dairy Board. Primary data was obtained directly from the respondents using questionnaires, observations and interviews. The respondents filled in the questionnaires but in cases of illiterate respondents the research assistants offered assistance. The instrument had return rate of $90.5 \%$.The researcher used Statistical Package for Social Sciences (SPSS) to analyze the data. The findings were presented in tables, pie charts and graphs. Cross tabulation and correlation analysis was used to establish the influence of the different independent variables and the dependent variable.

\subsection{Background Information of Dairy Farmers}

\section{Results and Discussions}

Various characteristics of the dairy farmers in Imenti South district and their businesses were analyzed including the gender, ages and levels of education. This background information was used to aid in interpreting the main research objectives.

Majority of the respondents were females at $50.6 \%$. However the difference was minimal with men at $49.4 \%$.This means there was near to equal representation of the two genders in the cooperative societies and milk marketing groups given the random selection of the respondents. This reflects equal ownership of dairy businesses and also access to the dairy benefits. This implies that support to dairy farming enterprises can be used to address any gender income disparities in Imenti South district.

The largest single category of farmers interviewed was aged between $31-40$ years at $32.6 \%$ as shown in figure 3 . The cumulative respondents below 40 years were $36 \%$, those below 50 years were $59.9 \%$ and those 
below 60 years $70.3 \%$.This was significant given the average age of farmers in Kenya as documented in the Agricultural Development Strategy 2009 to 2020 (GOK2009) at 60 years. This means dairy farming in Imenti South district is appealing to younger farmers and may be used to address the age disparities among farmers. This finding may also be linked to land ownership where youth are able to keep dairy cattle on small parcels of land under the zero grazing management system and sourcing the fodder from outside the farms.

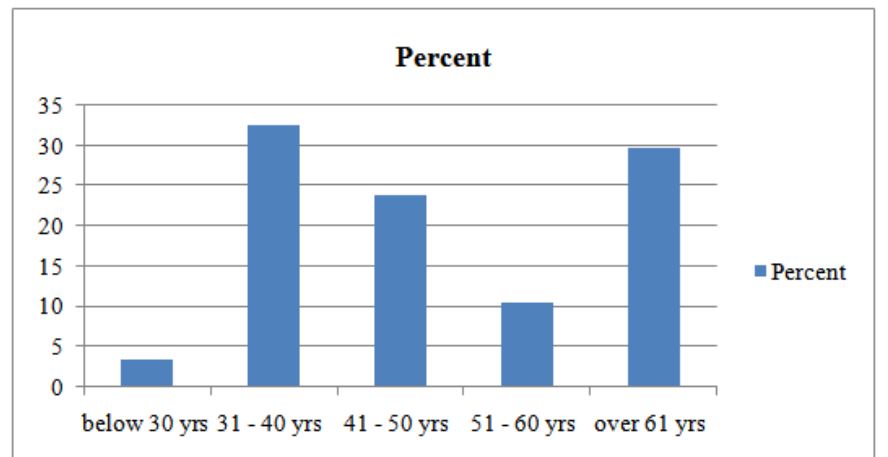

Figure 3: Age Brackets of Dairy Farmers in Imenti South District

Regarding the sizes of the households, $67.4 \%$ of the farmers had households of between 4 and 6 persons with $24 \%$ of the dairy farmers having less than three persons in their families. Only $1.2 \%$ of the households had 10 people and above.

Table 3: Size of House Holds

\begin{tabular}{lrrr}
\hline \multicolumn{4}{c}{ Table 3: Size of House Holds } \\
\hline & Frequency & Percent & Cumulative Percent \\
\hline $1-3$ & 42 & 24.4 & 24.4 \\
$4-6$ & 116 & 67.4 & 91.9 \\
$7-9$ & 12 & 7.0 & 98.8 \\
10 and above & 2 & 1.2 & 100.0 \\
\hline Total & 172 & 100.0 & \\
\hline
\end{tabular}

Most of the dairy farmers (60.4\%) had above secondary level of education and a further $2.3 \%$ of the respondents had gone up to university level as illustrated in figure 4.

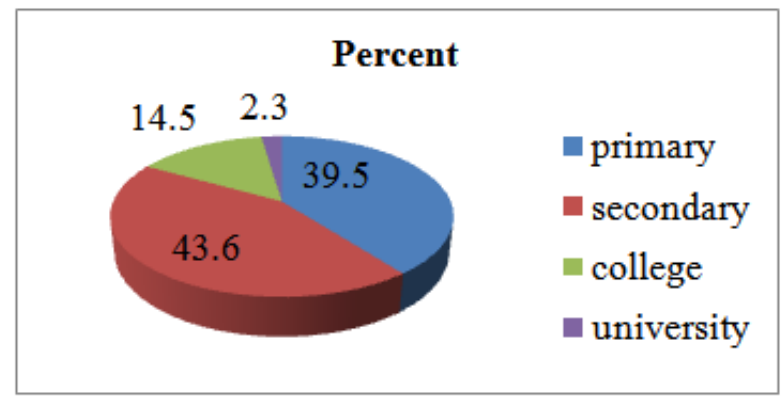

Figure 4: Dairy Farmers' Level of Education

This finding indicates a big potential to use modern approaches to extension encompassing Information communication technology (ICT) and an ability to keep proper business records because the majority of farmers have no limitation in reading and writing. However, this ability was not reflected in the business records managements as most of the dairy farmers $(87.8 \%)$ keep scanty, very scanty or no records cumulatively. This implies a need for training in this aspect of business management to the dairy farmers and possibly to the extension service providers. A training needs analysis is recommended to identify the exact knowledge and information gaps amongst both the farmers and the extension service providers in Imenti South district or why the majority of the dairy farmers are not keeping dairy business records in spite of the high level of education reported. 
Land sizes is an important factor in assessing farmers agri-business performances. It was established that majority of the respondents had less than 2 acres of land, representing a cumulative total of $71.5 \%$ of the total sample taken. Only $5.8 \%$ of the respondents had more than 5 acres of land as shown in table 4.

Table 4:Size of Farms

\begin{tabular}{llll}
\hline Acreage & Frequency & Percent & $\begin{array}{c}\text { Cumulative } \\
\text { Percent }\end{array}$ \\
\hline below 0.5 acres & 30 & 17.4 & 17.4 \\
0.5 - 1acres & 55 & 32.0 & 49.4 \\
1.1 - 2 acres & 38 & 22.1 & 71.5 \\
2.1 - 3 acres & 22 & 12.8 & 84.3 \\
3.1 - 4 acres & 11 & 6.4 & 90.7 \\
4.1 - 5 acres & 6 & 3.5 & 94.2 \\
above 5acres & 10 & 5.8 & 100.0 \\
\hline Total & 172 & 100.0 & \\
\hline
\end{tabular}

This finding implies that for any dairy farming business to be successful in the district the farmer must use modern farming methods involving high intensification of fodder production or incorporate feed importation from outside the farm in the business plan. This is especially important given $70.9 \%$ of the dairy farmers are also involved in cash crop and horticulture farming making land available for dairy farming even more scarce.

Farmers in Imenti South keep cattle for both commercial and subsistence purposes.70.3\% of the respondents keep their dairy cattle for commercial purpose and only $29.2 \%$ keep the dairy cattle for subsistence purposes as shown in table 5 .

Table 5: Purpose for Keeping Dairy Cattle

\begin{tabular}{lllll}
\hline Purpose & For cattle & Frequency & Percent & Cumulative Percent \\
\hline & commercial & 121 & 70.3 & 70.8 \\
& subsistence & 50 & 29.1 & 100.0 \\
& Total & 171 & 99.4 & \\
Missing & System & 1 & 0.6 & \\
\hline Total & & 172 & 100.0 & \\
\hline
\end{tabular}

This finding is in contradiction with (Karanja, 2003) who found that most smallholder farmers in Kenya view dairy as subsistence farming and not as a business. The high number of farmers who view their dairy farming as commercial is an indication of the farmers desire to commercialize dairy production in spite of the low incomes from dairy sales with up to $71.5 \%$ earning less than 10,000 shillings per month (see table 6). This is may imply inadequate knowledge or inadequate information on commercial dairy farming and hence the need for focused extension services especially on increasing productivity and on business management.

The study revealed that most dairy farmers in the study areas received low income per month from their dairy businesses. A majority of the dairy farmers (71.5\%) get an average of less than Ksh10, 000 from dairy farming every month as opposed to only 2 farmers (1.2\%) who had monthly earnings between Kshs 40,000 and Kshs 50,000 with none of the sampled respondents earning more than 50,000 per month (see table $6)$.

Table 6: Average Monthly Income of Dairy Farmers

\begin{tabular}{lllc}
\hline Income & Frequency & Percent & Cumulative Percent \\
\hline below 1000 & 9 & 5.2 & 5.2 \\
$1001-9999$ & 114 & 66.3 & 71.5 \\
$10001-19999$ & 40 & 23.3 & 94.8 \\
$20000-29999$ & 4 & 2.3 & 97.1 \\
$30000-39999$ & 3 & 1.7 & 98.8 \\
$40000-49999$ & 2 & 1.2 & 100.0 \\
\hline Total & 172 & 100.0 & \\
\hline
\end{tabular}


A majority of the dairy farmers, $39 \%$, rarely interacted with extension service providers. Only $27.7 \%$ felt they had frequent and very frequent interactions. Cumulatively, $72.4 \%$ of the dairy farmer were not having adequate interaction with dairy extension service providers as shown in table 7

Table 7: Interaction of Farmers with Dairy Extension Providers

\begin{tabular}{|c|c|c|c|c|}
\hline & Rate of interaction & Frequency & Percent & $\begin{array}{l}\text { Cumulative } \\
\text { Percent }\end{array}$ \\
\hline & none & 6 & 3.5 & 3.5 \\
\hline & rarely & 68 & 39.5 & 43.5 \\
\hline & moderate & 49 & 28.5 & 72.4 \\
\hline & frequent & 35 & 20.3 & 92.9 \\
\hline & very frequent & 12 & 7.0 & 100.0 \\
\hline & Total & 170 & 98.8 & \\
\hline Missing & System & 2 & 1.2 & \\
\hline Total & & 172 & 100.0 & \\
\hline
\end{tabular}

Most of the extension service providers were from the private sector with $70.3 \%$ as opposed to government extension officers representing $16.3 \%$. This finding is consistent with the low livestock extension officer to livestock farmer ratio of 1:2,000 reported in the district compared to 1:500 recommended in the agricultural sector development strategy 2009 to 2020 (GOK,2009). Further, 68\% of the respondents received extension services which were technical in nature and only $19 \%$ received service for market linkages. In addition, only $11.7 \%$ of the respondents got extension services on other aspects of business management. A cumulative $79.1 \%$ of the respondents having had none, few or very few trainings in business relate areas. Only $4.7 \%$ of the respondents received frequent management trainings

\subsection{The Influence of Farmer's Business Management Skills on Growth of Dairy Farming Enterprise.}

The study tried to establish the net effect of the training on performances of the dairy enterprises. As the monthly earnings increased, the numbers of dairy farmers who had not attended any business training decreased, with all farmers earning above 20,000 every month having attended some business management training. None of the farmers earning less than Ksh1, 000 every month had attended many or very many business management trainings.

It was also revealed that $45.5 \%$ of dairy farmers who had businesses valued at less than Kshs 20,000 had elaborate records while a further $34.6 \%$ of those dairy farmers who had between Kshs 21,000 and 50,000 had very elaborate records. It was noted that the highest return in this category which was $46.2 \%$ was of dairy farmers who had elaborate records and had businesses turnovers of between Kshs 151,000 and Kshs 200,000. Further, it was noted that $55.6 \%$ of those farmers who had elaborate records had businesses valued at over Kshs 500,000 . Hence there was a general increase in the monthly earning with better record keeping skills and a reduction in monthly earning with a reduction in the same. Thus good record management affects the growth of dairy business. Further research on this is recommended to determine what elements of record management affects growth of dairy business in Imenti south district. In this study record keeping was used as an indicator of business management skills. Business training and monthly income were correlated as in table 8

Table 8: Correlation Analysis of Business Trainings and Monthly Income

\begin{tabular}{|c|c|c|c|}
\hline & & $\begin{array}{l}\text { How many business } \\
\text { management trainings } \\
\text { have you attended }\end{array}$ & $\begin{array}{c}\text { On average how much } \\
\text { money do you get from } \\
\text { your dairy farming every } \\
\text { month }\end{array}$ \\
\hline \multirow{3}{*}{$\begin{array}{l}\text { How many business management } \\
\text { trainings have you attended }\end{array}$} & Pearson Correlation & 1 & $.151^{*}$ \\
\hline & Sig. (2-tailed) & & .049 \\
\hline & $\mathrm{N}$ & 172 & 172 \\
\hline \multirow{3}{*}{$\begin{array}{l}\text { On average how much money do you } \\
\text { get from your dairy farming every } \\
\text { month }\end{array}$} & Pearson Correlation & $.151^{*}$ & 1 \\
\hline & Sig. (2-tailed) & .049 & \\
\hline & $\mathrm{N}$ & 172 & 172 \\
\hline
\end{tabular}

*. Correlation is significant at the 0.05 level (2-tailed).

The computed correlation value between the amount of money generated per month from dairy farming and business management training attended was .151. This value is positive showing a positive relationship between the two variables. 


\subsection{The Influence of Extension Support Services on Growth of Dairy Farming Enterprises.}

The study concludes that $55.6 \%$ of those dairy farmers who had very frequent interaction with extension service providers earned between Kshs 40,000 and Kshs 49,999. A further $43 \%$ of the dairy farmers who had frequent interaction with the extension service providers reported an earning of between Kshs 1001 and 9999. There is a general increase in earnings per category with an increase in frequency of interactions with the extension service providers. Thus dairy farmers who have more interactions with the extension service providers are more likely to get higher monthly income from their dairy cattle in Imenti South district. Thus extension service providers influence earnings of the dairy farmers and therefore influence the growth of dairy farming enterprises in Imenti south district.

The number of dairy farmers who sought extension service from the government livestock officers increased with the increase in the size of the business with $9.1 \%$ of those with businesses valued at less than ksh20, 000 seeking service from them, $11.5 \%$ of those with businesses between 21,000 and 50,000 and 13.6\% of those with businesses valued at between 51,000 and 100,000 and 24.3\% with businesses between 101,000 and 150,000 seeking such service. There was a general decrease in the number of dairy farmers who sought extension service from neighbours and other sources as the size of the business increased. The number of dairy farmers who sought extension service from private service providers was constant among the different categories except for those with businesses valued at less than ksh20,000 who might have felt the costs of such services were too high and opted for other alternatives.

Table 9: Correlation Analysis of Monthly Income and Interaction With Dairy Extension providers

\begin{tabular}{|c|c|c|c|}
\hline & & $\begin{array}{c}\text { on average how much } \\
\text { money do you get from } \\
\text { your dairy farming every } \\
\text { month }\end{array}$ & $\begin{array}{l}\text { how would you rate your } \\
\text { interaction with dairy } \\
\text { extension providers }\end{array}$ \\
\hline \multirow{3}{*}{$\begin{array}{l}\text { on average how much money do you } \\
\text { get from your dairy farming every } \\
\text { month }\end{array}$} & Pearson Correlation & 1 & $* .358$ \\
\hline & Sig. (2-tailed) & & .253 \\
\hline & $\mathrm{N}$ & 172 & 170 \\
\hline \multirow{3}{*}{$\begin{array}{l}\text { how would you rate your interaction } \\
\text { with dairy extension providers }\end{array}$} & Pearson Correlation & .358 & 1 \\
\hline & Sig. (2-tailed) & .253 & \\
\hline & $\mathrm{N}$ & 170 & 170 \\
\hline
\end{tabular}

The researcher computed correlation between monthly incomes from dairy farming and the rate of interaction with dairy extension service providers and established the relationship at .358. This shows a positive relationship between monthly incomes from dairy farming and the rate of interaction with dairy extension service providers.

\section{Conclusion and Recommendation}

The study concludes that dairy farmers earning increased with better business management skills as indicated by record keeping. Reduction in monthly earning was also associated with a reduction in the records keeping. Thus better business management practices skills affect the growth of dairy enterprises. However, it is recommended that a further study is carried out to determine specific element of record management that affects growth of dairy farming in Imenti south district. It is also concluded that as the monthly earnings of the dairy farmers increased, the numbers of dairy farmers who had not attended business training decreased. Thus interaction with extension service providers affect growth of dairy farmers enterprises.

The study recommends that extension services to be enhanced specially from the government since the study has shown that this affects the growth of dairy farming in Imenti south district. In addition, dairy farmers in Imenti south district be trained on business management and in particular proper record keeping as this has been found to affect the growth of dairy business in Imenti south district. Also there is need to train the farmers on financial management as this area is not covered in the extension services offered by all the providers. It is recommended that in-service training be given to livestock extension officers on business management in areas like record keeping, financial management, business planning and marketing. Finally, the curriculum in agricultural training institutions to be reviewed and units in entrepreneurship and agri-business included to strengthen business related competencies of the extension service providers. 


\section{References}

[1]. Churchill, C. N. and Lewis, V. L. (1983). "Growing Concerns: The Five Stages of Small Business Growth," Harvard Business Review, 3: 30-50.

[2]. Evenson. Robert and Germano Mwabu (1998) The effects of agricultural extension on farm yields in Kenya. Economic Growth Center, Yale University center discussion paper no. 798

[3]. East Africa Dairy Development Program (2008): The Dairy Value Chain in Kenya .A report by Techno Serve Kenya

[4]. Food and Agricultural Organization (2010) A Summary of Milk Production across the World

[5]. GoK. (2011). District Livestock Production Imenti South District, Annual Report. Unpublished Report.

[6]. $\quad$......... (2010): Kenya national dairy master plan Ministry of Livestock Development .Government printer, Nairobi, Kenya.

[7]. $\quad$......... (2009) Agricultural sector development strategy (ASDS) 2009 - 2020.Government printer, Nairobi, Kenya.

[8]. $\quad$........ (2008): Ministry of Livestock Development Sessional Paper No.2 of 2008 on National livestock policy. Government printer, Nairobi, Kenya

[9]. Haggblade, S. (2011),"Modernizing African Agribusiness: Reflections for the Future", Journal of Agribusiness in Developing and Emerging Economies, Vol. 1 Iss: 1 pp. $10-30$

[10]. Karanja A.M .(2003). The Dairy Industry in Kenya: The Post Liberalization Agenda. Unpublished Reort.

[11]. Kothari, C. R (2004). Research methodology: Methods \&Techniques. New Delhi: New Age International

[12]. Mbogo,M .(2011). Influence of Managerial Accounting Skills on SME's on the Success and Growth of Small and Medium Enterprises in Kenya. Journal of Language, Technology \& Entrepreneurship in Africa Vol. 3 No. 1

[13]. Mburu, L. M., Wakhungu, J.W. and Gitu, K.W. (2007): Determinants Of Smallholder Dairy Farmers' Adoption of Various Milk Marketing Channels in Kenya Highlands. Livestock Research for Rural Development, 19, (9).

[14]. $\quad$........... (2007): A Cost-Benefit Analysis of Smallholder Dairy Cattle Enterprises in Different Agro-Ecological Zones in Kenya Highlands: Livestock Research for Rural Development 19 (7)

[15]. Muchai, W, P. (1999). Investigation of the Causes Of Failure And Ways Of Improving Performance of Small Enterprises : Case Study of Smallholder Dairy Sector In Kikuyu And Limuru Divisions of Kiambu District: MBA Project, Kenyatta university, Unpublished.

[16]. Mugenda, O.M and Mugenda, A.G (2003). Research Methods: Quantitative and Qualitative techniques, Nairobi: ACTS Press.

[17]. ............. (1999). Research Methods, Qualitative and quantitative approaches. Nairobi: Acts Press.

[18]. Muyanga, T. and Jayne, S. (2006). Agricultural Extension in Kenya: practice and policy lessons: Tegemeo Institute of Agricultural Policy and Development

[19]. Muriuki, H. G. (2003). Milk and Dairy Products, Post-harvest Losses and Food Safety in Sub-Saharan Africa and the Near East: A Review of the Small Scale Dairy Sector - Kenya. Rome, Italy: Food and Agricultural Organization.

[20]. Ngigi, M., Ahmed, M.A., Ehui, S. and Assefa, Y. (2010), "Smallholder dairying in Eastern Africa", in Haggblade, S. and Hazell, P.B.R. (Eds), Successes in African Agriculture: Lessons for the Future, Johns Hopkins University Press, Baltimore MD, pp. $209-61$.

[21]. O'Regan, N. \& Ghobadian, A. (2004).Testing the Homogeneity of SMEs-The Impact of Size on Managerial and Organization Processes.Euro Business Review.16 (1):p.p 64-79

[22]. Wambugu.S, Kirimi.L and Opiyo.J, (2011): productivity trends and performance of dairy farming in Kenya Tegemeo institute of agricultural policy and development 